\title{
Forest and Peatland Fire Dynamics in South Sumatra Province
}

\author{
Ati Dwi Nurhayati ${ }^{1^{*}}$, Bambang Hero Saharjo ${ }^{2}$, Leti Sundawati ${ }^{3}$, Syartinilia ${ }^{4}$, and Mark A. Cochrane ${ }^{5}$ \\ 1 Program of Natural Resources and Environmental Management Science, IPB University, Indonesia \\ 2 Department of Silviculture Faculty of Forestry and Environment, IPB University, Indonesia \\ 3 Department of Forest Management Faculty of Forestry and Environment, IPB University, Indonesia \\ 4 Department of Landscape Architecture Faculty of Agriculture, IPB University, Indonesia \\ 5 Appalachian Laboratory, University of Maryland Center for Environmental Science, United States \\ * Correspondence author: awinur@apps.ipb.ac.id
}

\begin{abstract}
South Sumatra Province experiences forest and land fires every year. Peatland and human activity have caused this region to be more vulnerable to fire. In this study, we used annual mapping to describe the history of forest and land fires in Ogan Komering Ilir (OKI) District of South Sumatra to analyze fire trends during the 2015-2019 period. Hotspot data were obtained from Terra/Aqua MODIS satellite imagery at all confidence levels. Burned areas were identified using the Normalized Burn Ratio (NBR) Index, with data sources from Landsat 8 satellite imagery obtained from the USGS (United States Geological Survey). The highest number of hotspots were detected in 2015 (33,748), with 72\% was located on peatland. Historical analysis of hotspot numbers, shows that the majority of burning occurs in September and October. This indicates that prevention activities must be carried out more intensively before these months. Linear regression between annual hotspot numbers and rainfall was not significant. Hotspots indicative of forest and land fire in OKI District were more influenced by human activities. The largest burned area $(993,999 \mathrm{ha})$ occurred in 2015. The 2015 El Niño event triggered drought and worsened forest and land fires in Indonesia. Although no El- Niño conditions occurred in 2016-2018, fires continued to occur in OKI District, showing their independence from extreme drought. The fires occurring on peatlands burned a large area during 2015-2019 indicating that forest and land fires management must become a top priority in OKI District.
\end{abstract}

Keywords: Burned area; Hotspot numbers; Peatland fires; South Sumatra; Ogan Komering Ilir; Rainfall.

\section{Introduction}

Forest and land fires occur almost every year in Indonesia. Indonesia experienced the most severe fires in the world during the El Niño phenomenon of 1997/1998 with a burned area of $11,698,379$ hectares, approximately 624,000 hectares of which occurred in the Sumatran peat swamps (Tacconi, 2003; Bappenas-ADB, 1999). The air pollution from dense haze that year came mostly from forest and peatland fires. Another major El-Niño event occurred in 2015, resulting in the biggest fires of the last decade. Climate and weather determine the length and severity of the fire season (Chandler et al., 1983). Total burned area in 2015 was 2.61 million hectares, approximately $33 \%$ of which occurred on peatland, with $67 \%$ occurring on mineral soils (MoEF, 2016). In 2019, more severe fires burned approximately 1.64 million hectares (MoEF 2020). The history of forest fires in Indonesia clearly shows that fires are regularly burning in peatland areas, not only on mineral soils. Peatland fires cause more severe environmental impacts than those on mineral soils. Smoke sampling, conducted in Central Kalimantan Province, recorded that there are more than 90 gases produced from peat fires, including greenhouse gases and other gases harmful to human health (Stockwell et al., 2016). Haze from peat fires can cause transboundary haze pollution. Forest and peatland fires in 2015 caused such haze to spread to neighboring countries including Malaysia, Singapore and a portion of Thailand (MoEF, 2015). This affected the relationships between Indonesia and neighboring countries.

Indonesia has the fourth largest area of peat in the world after Canada, Russia and the United States (Maltby \& Immirzi, 1993). The peatland area in Indonesia is approximately $14,905,575$ hectares spread across Sumatra $43.18 \%$, Kalimantan $32.06 \%$ and Papua $24.76 \%$ (BBSDLP 2011). However, in the last few decades, the peatland areas in Indonesia have increasingly come under threat. Peatlands are converted for many purposes, including agricultural land, plantations, forestry, 
and settlements, all of which cause the peatlands become degraded (Wahyunto. et al., 2013). Naturally, peat is usually saturated with water. However, if peatlands are degraded due to forest clearing or drainage, water is lost from the system and the near-surface peat becomes dry (Taufik et al., 2015; Turetsky et al., 2015). Once drained, subsidence can compact the peat, leading to irreversible drying, increased flammability and low pH (Andriesse, 1988).

Indigenous peoples have influenced the occurrence of surface fires in forests and other lands for a very long time (Conrad, 2009). However, peatlands do not naturally experience subsurface burning within the peat when influenced only by weather and fuel factors. Human activities have been the trigger igniting the vast majority of peatland fires (Cattau et al., 2016; Page \& Hooijer, 2012). Once ignited in the drained peatlands, subsurface fires, burning within the peat, are not influenced by wind, so the direction of spread is uncertain, making it is difficult to determine where the burning will actually occur (Saharjo et al., 2017). Peat has an extremely important role in global climate change. Forest and peatland fires increase greenhouse gas emissions released into the air which contribute to global climate change (Masganti et al, 2014). The monetary losses from the 2015 fires were estimated at USD 16.1 billion (World Bank 2016).

South Sumatra Province has the second largest area of peat (1.48 million ha) on the island of Sumatra after Riau (Wahyunto \& Haryanto 2005). South Sumatra experienced the most fires of any province in 2015, with a total burned area of 646,298 hectares (Trinimalingrum et al., 2015), and another 336,798 hectares in 2019 (MoEF, 2020). Consequently, the Indonesian government has designated South Sumatra as one of provinces prone to fires (MoEF 2015). South Sumatra consists of 13 regencies; however, Ogan Komering Ilir (OKI) is a District which burns every year. In 2015 and 2019, human activities in OKI District caused extensive peatland areas to burn more severely than in other Districts. However, information regarding the historical trends of forest and land fires, especially on peatlands in Oki District, is still limited. The objectives of this study were to: (1) analyze the trends of hotspots and their dynamics during the 2015-2019 period; (2) analyze the relationship between hotspots and rainfall; (3) obtain the extent of fires, especially on peatlands; (4) analyze the relationship between hotspots and burned area. The results of this study can be used as baseline information to determine better strategies for preventing forest and land fires in OKI District.

\section{Materials and Methods}

\subsection{Study Area}

The study was conducted in OKI District (Figure 1). OKI District has an average elevation of 10 meters above sea level and is located between $2^{\circ} 30^{\prime}$ north latitude and $4^{\circ} 15^{\prime}$ south latitude, $104^{\circ} 20^{\prime}$ and $106^{\circ} 00^{\prime}$ east longitude and covers $19,023.47 \mathrm{~km}^{2}$. OKI District has a tropical climate. The dry season is typically from May to October every year, and rainy season is from October to April. Exceptional droughts can extend dry season conditions longer than usual. Average annual rainfall was 2,522 $\mathrm{mm}$ during the period of analysis. Agriculture is the main sector activity in OKI District, providing significant contribution to the economic income of the region (BPS Statistic of Ogan Komering llir, 2018).

\subsection{Data and Source}

In this study, hotspot data were obtained at all confidence levels from both Terra and Aqua MODIS active fire products, downloaded from NASA (https://firms.modaps.eosdis.nasa.gov/download/). The Normalized Burn Ratio (NBR) was used to map burned areas in Landsat imagery. The top of atmospheric reflectance values from two Landsat 8 bands (Near Infrared and Shortwave Infrared) were used to derive the NBR index. The images were downloaded from the Centre for Technology and Remote Sensing Data LAPAN and the United States Geological Survey. The dataset covered the entire OKI District area from 2015 to 2019. Table 1 summarizes all data sources used in this study. 


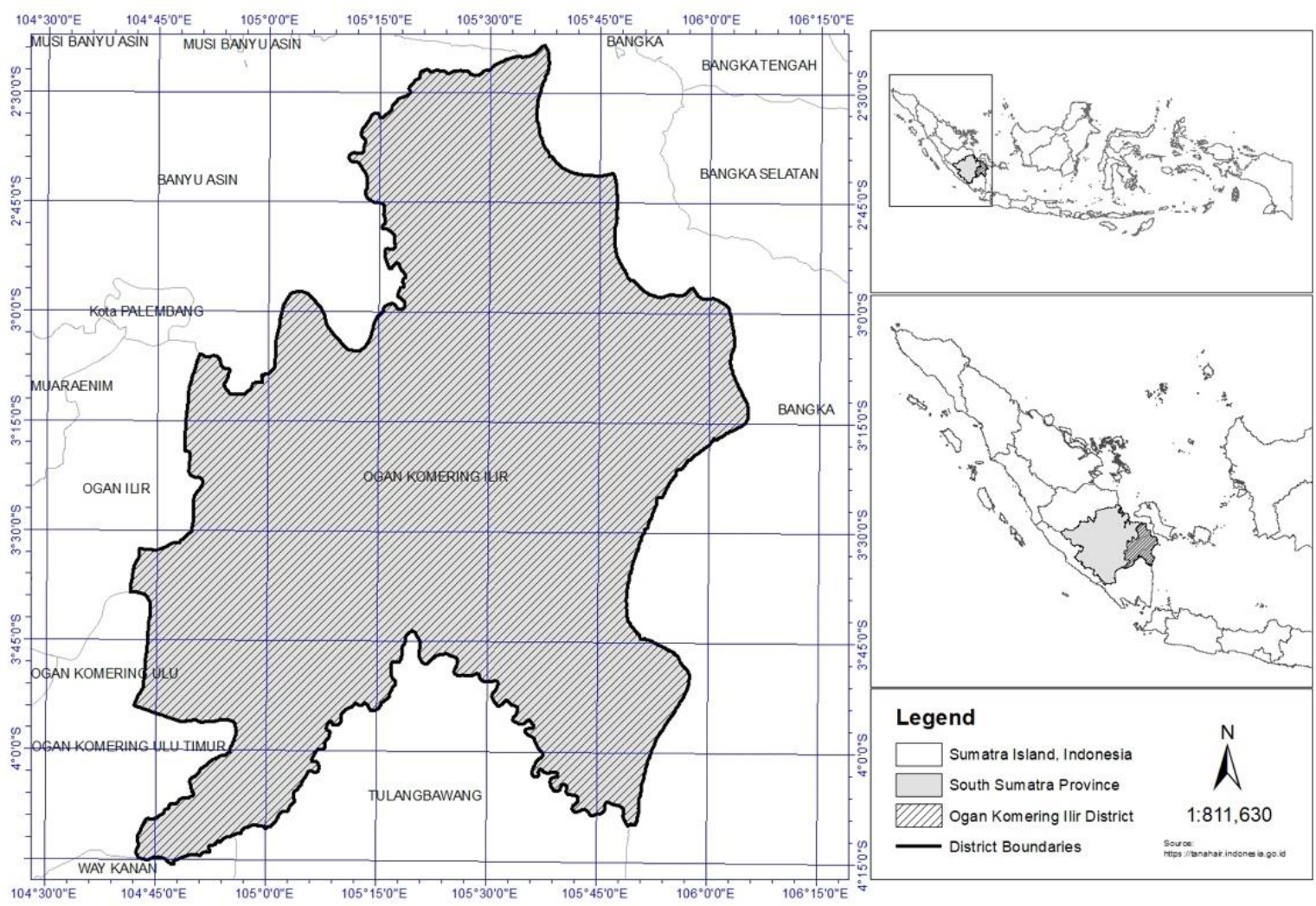

Figure 1. Location of the study area, Ogan Komering Ilir District, South Sumatra

Daily rainfall data from 2015 to 2019 were used to investigate the relationship with hotspots. The datasets were downloaded from the National Agency of Meteorology, Climatology, and Geophysics (BMKG) at https://dataonline.bmkg.go.id/home.

Table 1. Data sources and selection to map the burned areas from 2015-2019

\begin{tabular}{ccccccc}
\hline Data Source & Path Row & $\mathbf{2 0 1 5}$ & $\mathbf{2 0 1 6}$ & $\mathbf{2 0 1 7}$ & $\mathbf{2 0 1 8}$ & $\mathbf{2 0 1 9}$ \\
\hline Landsat Imagery (Pre-Fire) & 123062 & Jan-Jun & Jan-Jun & Jan-Jul & Jan-Jul & Jan-Sep \\
& 123063 & Jan-Jun & Jan-Jun & Jan-Jul & Jan-Jul & Jan-Sep \\
& 124062 & Jan-Jun & Jan-Jun & Jan-Jul & Jan-Jul & Jan-Sep \\
& 124063 & Jan-Jun & Jan-Jun & Jan-Jul & Jan-Jul & Jan-Sep \\
Landsat Imagery (Post-Fire) & 123062 & Jul-Nov & Jul-Oct & Aug-Oct & Aug-Oct & Oct-Dec \\
& 123063 & Jul-Nov & Jul-Oct & Aug-Oct & Aug-Oct & Oct-Dec \\
& 124062 & Jul-Nov & Jul-Oct & Aug-Oct & Aug-Oct & Oct-Dec \\
& 124063 & Jul-Nov & Jul-Oct & Aug-Oct & Aug-Oct & Oct-Dec \\
Hotspot & NASA FIRMS & & & & & \\
\hline
\end{tabular}

\subsection{Burned Area Analysis}

The Normalized Burn Ratio (NBR) Index was used to identify burned areas in major fire zones. The equation incorporates both the near infrared (NIR) and shortwave infrared radiation (SWIR) bands. Healthy vegetation exhibits a high level of reflection in the NIR and a low level of reflection in the SWIR, opposite of what is observed in areas affected by fire. The burned areas have a low reflectance in the near-infrared band and a high reflectance in the SWIR band. NBR makes use of the ratio between the NIR and SWIR bands to exploit the large spectral differences. A positive NBR value indicates healthy vegetation, whereas a negative value indicates bare land or areas that have recently burned. Typically, in unburned areas the difference in NBR values between two time periods is close to zero (García \& Caselles., 1991). The following formula was used to calculate the NBR index. 
Where:

$$
N B R=\frac{N I R-S W I R}{N I R+S W I R}
$$

NBR : Normalized Burn Ratio

NIR : Near Infrared

SWIR : Shortwave Infrared

In this study, Linear Regression Analysis was used to analyze the relationship between annual rainfall and annual hotspot numbers and also the relationship between annual hotspot numbers and annual burned area. This analysis was based on the functional or causal relationship between one independent variable and one dependent variable. The implementation steps of this study are shown in Figure 2.

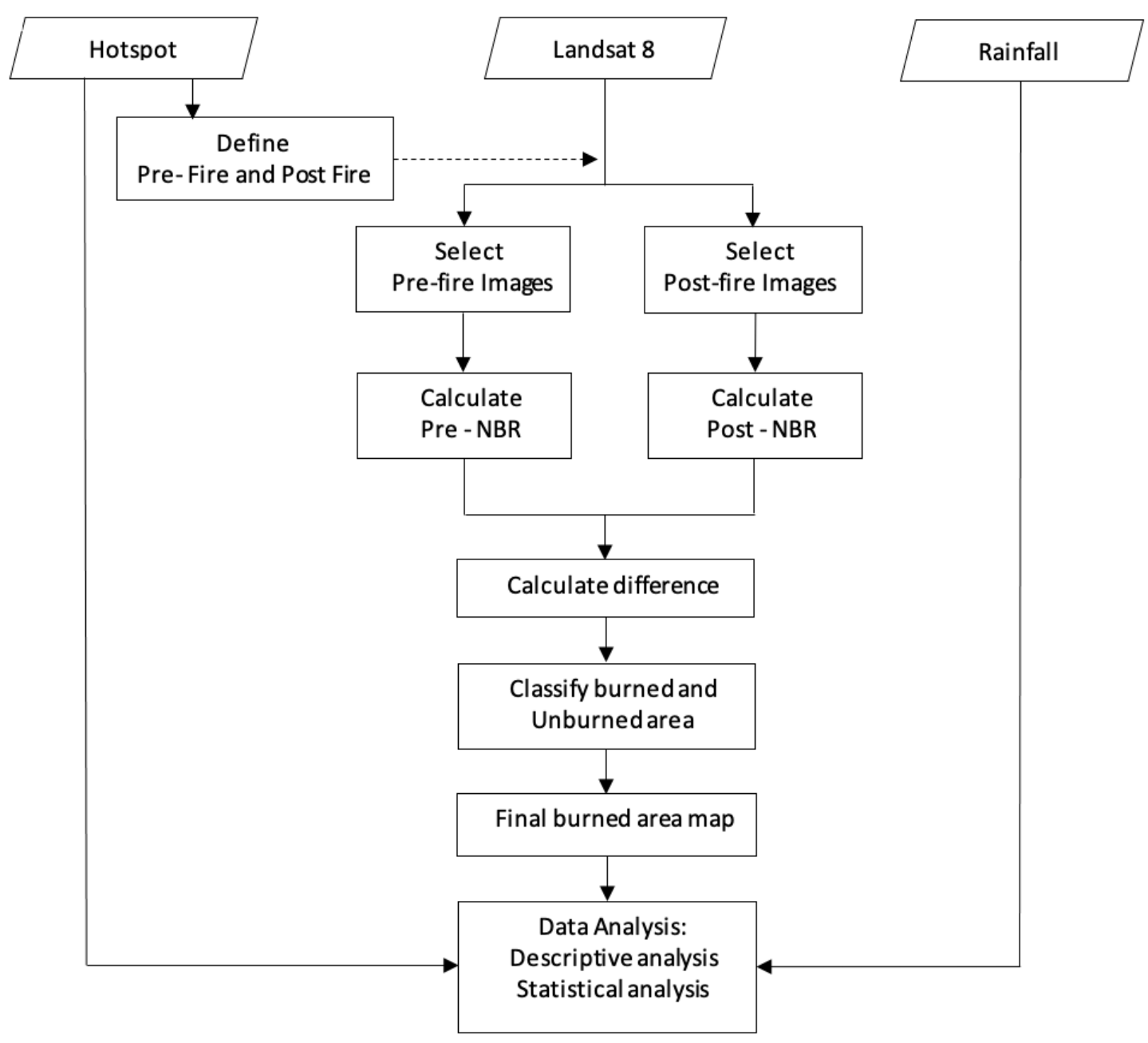

Figure 2. Flow Chart of Study Implementation

\section{Results and Discussion}

\subsection{The number of hotspots and rainfall in the period of $2015-2019$}

Hotspots are remotely sensed indicators of forest and land fires that have higher temperatures, above a certain threshold (P.8/MENLHK/SETJEN/KUM.1/3/2018). Although hotspots do not necessarily mean fires, they can be used to identify forest and land fires at early stages (Endrawati, 2016). The number of hotspots during this period in OKI District fluctuated widely between years. Based on MODIS data from the Terra/Aqua satellites (Table 2), the highest hotspot number $(33,748)$ was found in 2015 with 24,362 hotspots (72\%) located on peatland. In 2016, hotspot numbers decreased to a mere 308 hotspots, with 84 hotspots (27\%) located on peatland. In 2017, the number of hotspots increased slightly to 475 hotspots, however, in 2018 , hotspots increased rapidly to 
2,592 , with 704 hotspots (27\%) on peatland. Serious levels of burning returned in 2019 , with the number of hotspots increasing substantially to 30,630 , with 14,308 hotspots $(47 \%)$ on peatland.

Table 2. Annual hotspot number at OKI District in the period of 2015-2019

\begin{tabular}{rrr}
\hline \multirow{2}{*}{ Years } & \multicolumn{2}{c}{ Hotspot Number } \\
\cline { 2 - 3 } & Peat & Mineral Soil \\
\hline 2015 & 24,362 & 9,386 \\
2016 & 84 & 224 \\
2017 & 148 & 327 \\
2018 & 704 & 1,888 \\
2019 & 14,308 & 16,322 \\
\hline
\end{tabular}

OKI District has the largest peat area (768,501 ha) in South Sumatra Province (Wahyunto et al., 2005). The peat is a wetland ecosystem that naturally stores a large amount of carbon (Hooijer et al., 2006; Joosten, 2009; Whelan, 1995) and provides an important source of livelihoods for local communities. The high levels of human activity on peatlands can be a threat to the sustainability of these ecosystems since fire is often used to manage the land after drainage, increasing the vulnerability to subsurface peat fires (Nurhayati et al. 2020). The data clearly show that the annual numbers of hotspots on peatlands in this district are much higher than would naturally be expected and justify making it a priority area for forest and peatland fires management. Forest and peatland fires increase greenhouse gas emissions into the air and contribute to global climate change (Masganti et al. 2014). Figure 3 shows that 2015 and 2019 had the densest hotspot distributions, while 2016-2018 had much lower hotspot numbers. Both the NINO 3.4 SST Index and Southern Oscillation Index indicate that 2015 had a strong El Niño event (Yananto \& Dewi, 2016), whereas the El Niño in 2019 was weaker (BMKG, 2019). El- Niño events are associated with droughts in this region which had a clear impact on the density of hotspots in 2015 and 2019 as compared the other years which did not have El Niño conditions.

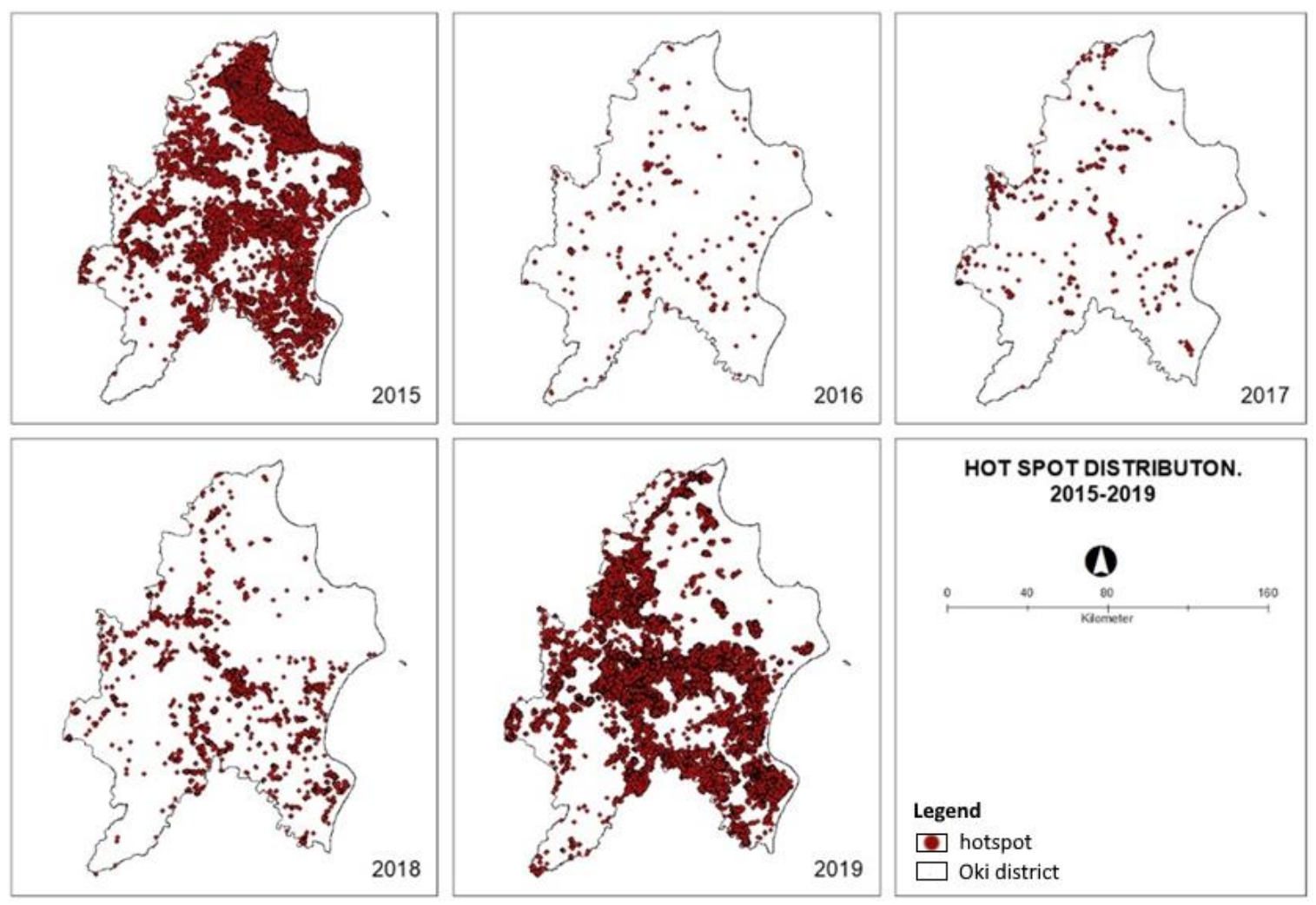

Figure 3. Annual Hotspot distribution at OKI District in the period of 2015-2019

Figure 4 shows that the numbers of hotspots from December until June, corresponding to the wet and early dry seasons, tend to be low but start rising in July as the dry season strengthens. The number of hotspots increases significantly and usually peaks in October; however, during El Niño 
conditions, large amounts of hotspots may be observed into November. In OKI District, September and October are the months most prone to fires and prevention activities are most critical at this time.

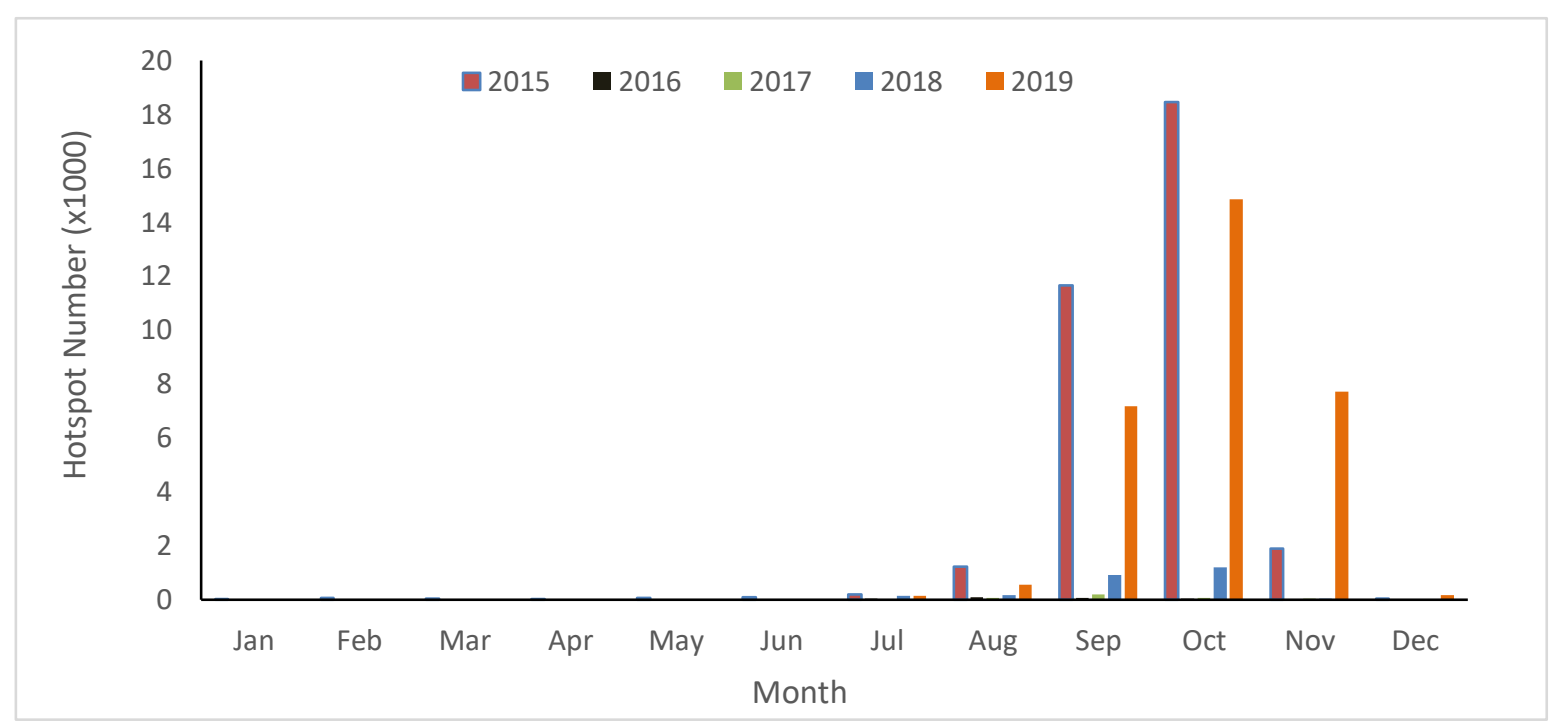

Figure 4. Monthly hotspot distribution at OKI District in the period of 2015 - 2019

Figure 5 shows the distribution of hotspots and monthly rainfall in OKI District. There was a strong relationship between rainfall and hotspot number from both MODIS Terra/Aqua and NOAA satellite data (Syaufina et al., 2014). In 2015, OKI District experienced a dry season starting from July $(21 \mathrm{~mm}$ rainfall) and reached peak intensity in September and October $(0 \mathrm{~mm})$ when no detectable rain fell. The number of hotspots in 2015 increased significantly as the dry season continued, rapidly growing to 11,647 in September and reaching 18,456 in October during this extremely dry period.

In 2016, by way of comparison, the highest number hotspots (90) were found in August, dropping to just a single hotspot in November. This dramatic reduction in hotspots was likely due to the extremely high annual rainfall $(3,503 \mathrm{~mm})$ that year. In 2017 hotspot numbers increased slightly from 2016, reaching a peak of 199 in September, the third consecutive month with rainfall amounts less than $100 \mathrm{~mm}$. In 2016, only a single month dipped below $100 \mathrm{~mm}$. The annual rainfall decreased slightly in 2018 (2,559 mm) compared to 2017 (2,647 mm). Indonesia began experiencing a weak ElNiño in October 2018 and only returned to normal conditions by the end of 2019 (BMKG 2019). The number of hotspots in 2018 began increasing in July and peaked at 1,206 hotspots in October. During the ongoing El Niño event in 2019, hotspot numbers increased to 7,165 in September and reached 14,844 by the peak in October. The dry season in 2019 (July - November) had the lowest monthly rainfall $(0.5 \mathrm{~mm})$ in August. 


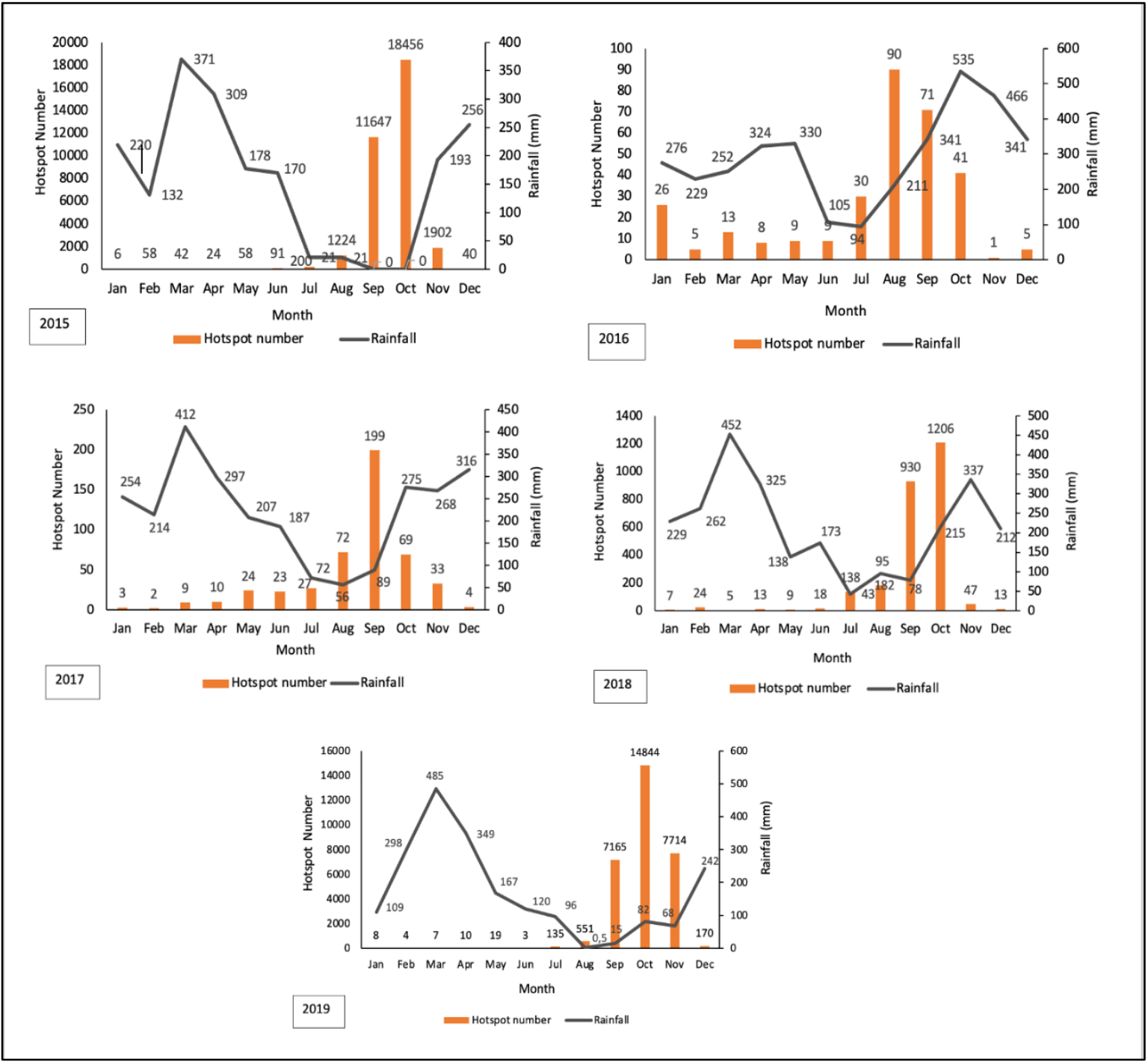

Figure 5. Monthly hotspot and rainfall distribution at OKI District in the period of $2015-2019$

\subsection{The Relationship between Annual Hotspot Number and Rainfall}

A linear regression analysis of hotspot numbers and annual rainfall was not significant ( $P$ value $=0.078$ ); therefore, simple modeling with only annual rainfall is not sufficient for predicting the number of hotspots in any given year. The hotspot regression coefficient was negative (-22.236), indicating that the effect of the variable rainfall on the number of hotspots was inversely proportional. The negative relationship between hotspot number and annual rainfall can be seen more clearly in Figure 6, showing that hotspot numbers fell dramatically as annual rainfall increased from 2000-2500 mm. Although rainfall did not directly influence the number of hotspots as a fire indicator, it was an important factor influencing fuel moisture contents. As fuel moisture content drops this increases the flammability of the fuels.

Another factor strongly associated with the appearance of hotspots as forest and land fire indicators in OKI District is human land management activity. Although there has been a government prohibition on using fire in land preparation, it is still widely used because it is considered cheaper, easier, and faster than zero burning. Previous work has shown that the appearance of hotspots in the region is always related to forest and land clearing activities that are often conducted by burning. The cost of using fire in land clearing is only one-third to a quarter of zero burning techniques (Saharjo, 2006). 


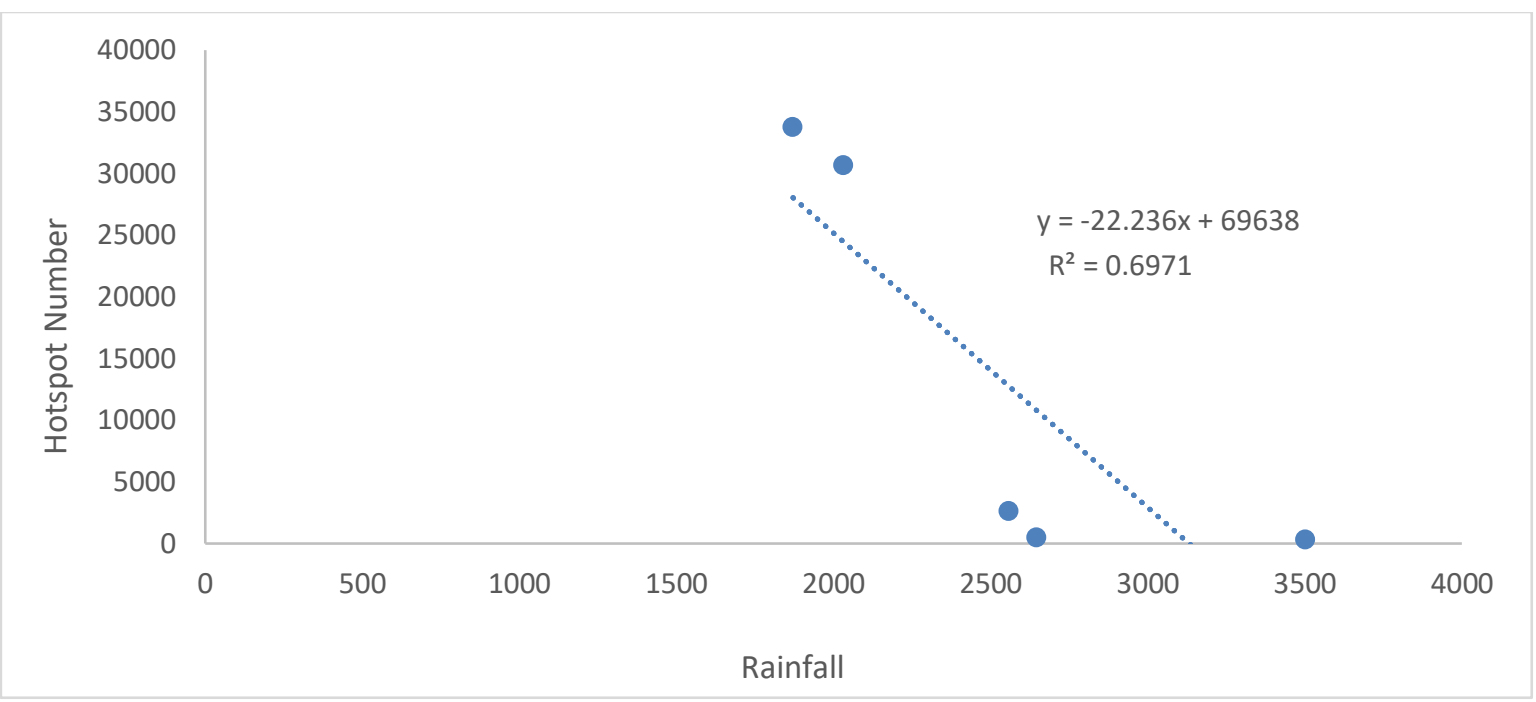

Figure 6. Relationship between hotspot number and annual rainfall at OKI District in the period of 2015-2019

\subsection{Burned Areas in the Period of 2015 - 2019}

Based on the identification of burned areas in OKI District using Landsat 8 (Figure 7), the highest annual burned area occurred in 2015. The total burned area was 948,550 hectares, consisting of 410,132 hectares on peatland area and 538,418 hectares on mineral soils. The El Niño conditions in Indonesia in July 2015 triggered drought and worsened forest and land fires. Indonesia experienced severe forest and land fire in 2015, which burned peatland area of about 869,794 hectares (Trinimalingrum et al., 2015), and approximately $47.5 \%$ was located in OKI District.

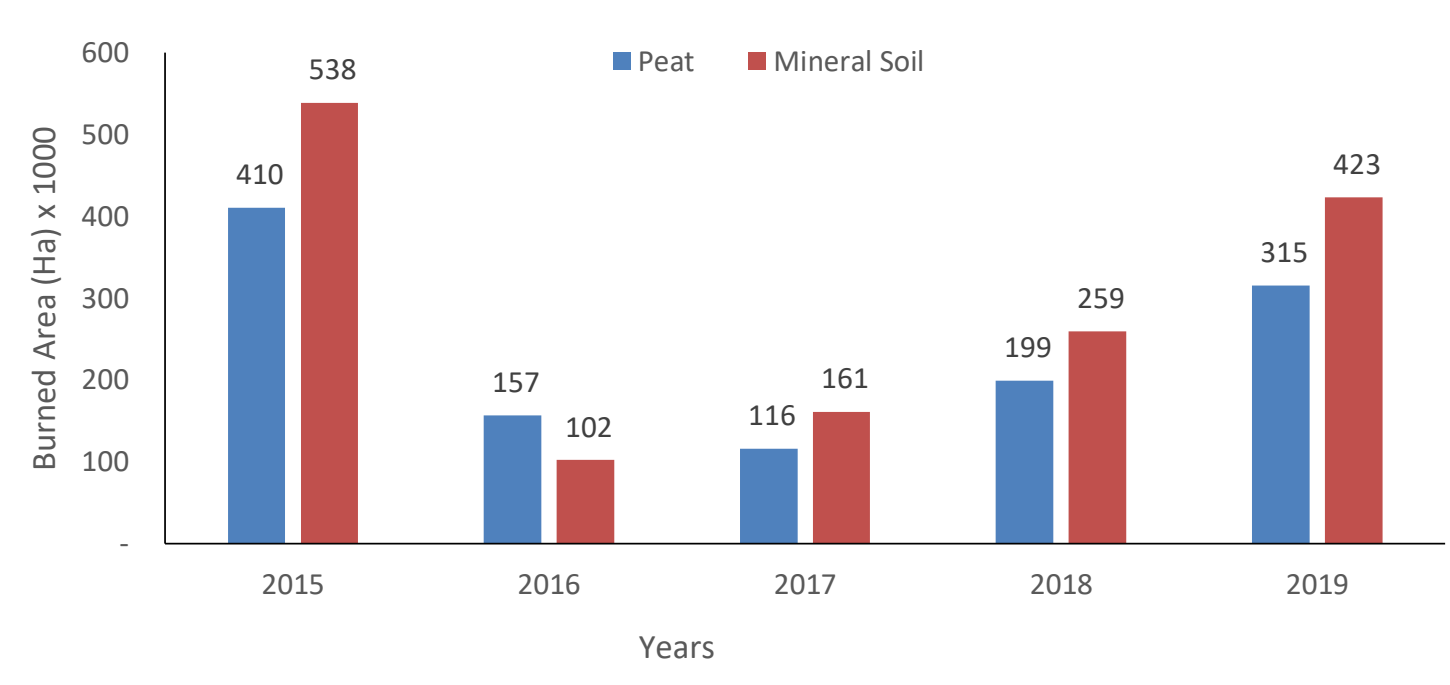

Figure 7. Temporal distributions of burned area at OKI District in the period of 2015-2019

In 2016, burned area decreased significantly (72.8\%) from the previous year. The burned area was approximately 258,521 hectares, with 156,775 hectares on peatland and 101,747 hectares on mineral soils. The decrease of forest and land fires was associated with strong La Nina conditions that increased rainfall during the dry season. In addition, due to the severe impacts of forest and land fires in 2015, the government had increased efforts to control forest and land fires in accordance with a decree by the Indonesian President that specified use of an early warning system, law enforcement, encouragement of community participation in preventing forest fires, air patrolling, improvements in forest and land governance, as well as coordination and synergy between the central and regional governments (MoEF 2017). In 2017, burned area in OKI District increased by $15 \%$ (Figure 7). Total burned area was 276,617 ha, with 115,717 ha (37.8\%) on 
peatlands. In 2018, burned area increased by another $65 \%$ from the previous year, reaching 457,633 ha, 198,970 hectares of which occurred on peatlands. In 2019, the burned area in OKI District increased even further to 738,219 ha, with 314,851 ha on peatlands. Although weak, El-Niño conditions in 2018-2019 exacerbated the incidence of fires during this period.

Regardless of the number of hotspots, the spatial distribution of burned area each year (20152019; Figure 8) shows that substantial amounts of forest and land fires occur every year in OKI District. Even though there was no El- Niño phenomenon during 2016-2018, forest and land fires still continued to occur. Forest fire management, especially prevention, must become the top priority in OKI District to reduce the amount of perennial burning. Approximately $40 \%$ of OKI District area is covered by peatlands. During the study period (2015-2019), the fires occurring on peatlands were numerous and quite large. In 2015, more than half of the peatland areas in OKI District burned $(53.4 \%)$ and in 2019 , nearly half of the peatland area $(41 \%)$ burned again. The peat fires are associated with human activities utilizing peatlands. Growing populations require continued conversion of peatlands to agricultural land in order to support the food security, fulfillment of raw materials for the paper industry, and requirements for plantation areas (Widyati, 2011).
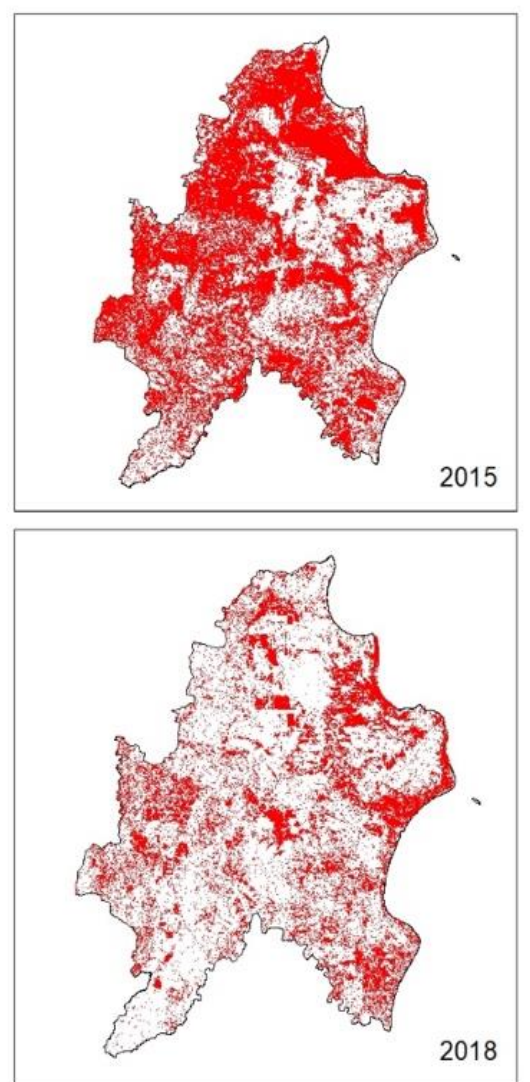
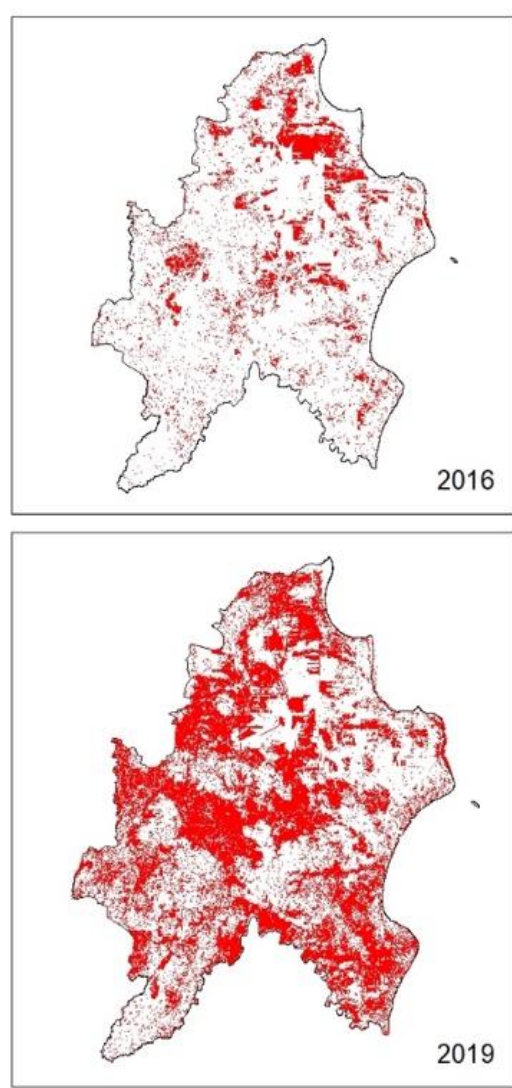

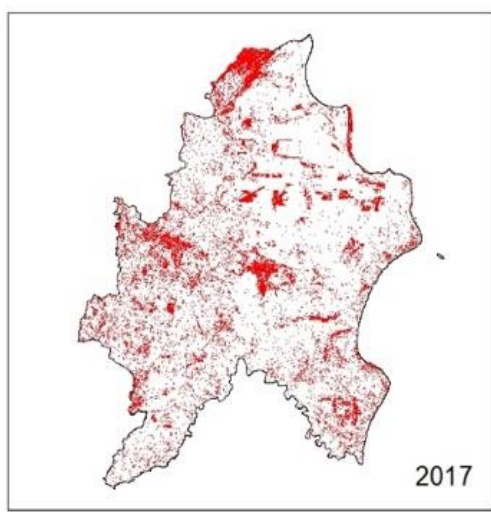

BURN AREA DISTRIBUTION 2015-2019

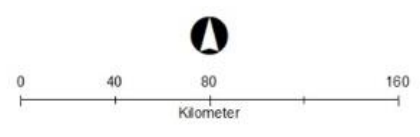

Legend

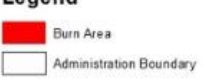

Figure 8. Spatial distribution of burned area at OKI District during 2015-2019

Nearly $100 \%$ of forest and land fires in Indonesia are caused by human activities (Syaufina, 2008). The high intensity of human activities on peatland greatly increases the opportunities for forest and peatland fires. Improperly managed drainage canals cause the groundwater level to drop too far, leading the peat to become overly dry and prone to fires in the dry season. Based on Government Regulation Number: 57/2016 regarding the protection and management of peat ecosystems, having groundwater levels (GWL) more than $0.4 \mathrm{~m}$ below the peat surface is the standard criteria for considering peat damaged in cultivation areas. However, degraded forests and peatlands are more susceptible to fire and must be maintained in wetter conditions, with a critical GWL at $10 \mathrm{~cm}$ below the surface (Putra et al., 2018). Tulung Selapan sub-District in OKI District is dominated by peatlands degraded by logging or land conversion to oil palm plantations and it has been the largest contributor of haze from fires in South Sumatra Province (Solichin 2004). 
Previous studies have found that the majority of human actions that can cause forest and peatland fires in OKI District are related to the sonor system of land management (Nurhayati et al. 2020). Sonor is a system for preparing agricultural land by burning the peat surface to open the area and release important nutrients for rice to grow (Larastiti, 2018). Rice planting using sonor is usually conducted during a long dry season and is a longstanding practice that is still used by local populations in South Sumatra (Ratmini \& Yohanes, 2014). Land preparation activities by communities and companies are the most common causes of fires in South Sumatra (Tarigan et al. 2015). Fire prevention activities in forest and peatland areas of Oki District need to focus on the human element.

\section{Conclusions}

The highest number of hotspots within the previous five years in OKI District was found in 2015, with roughly $72 \%$ located on peatlands, and the second highest was in $2019,47 \%$ of which was found on peatland. Examination of the number of hotspots throughout the years revealed the typical seasonality of hotspots in OKI District, with increasing numbers starting in July and reaching peak levels in September-October. This period corresponds with the lowest average monthly rainfall levels for 2015-2019, excluding the unusually wet La Nina year of 2016. Regression equations between annual hotspot numbers and annual rainfall were not significant ( $P$ value $=0.078$ ); therefore, rainfall data alone cannot be used to predict hotspot numbers in the corresponding year. This is not a surprising result since forest and land fires are most closely associated with human land management activities in OKI District.

OKI District also experienced the two greatest areas burned by forest and land fires in 2015 and 2019, respectively. Severe drought conditions spawned by EI Niño conditions exacerbated fires in both 2015 and 2019 causing burned area in peatlands as well as on mineral soils to be very high. More than half of the peatland area in OKI District burned in 2015 (53.4\%) and close to half burned again in 2019 (41\%). Though smaller in extent, fires still occurred in Oki District during the 2016 2018 period even though there was no El Niño, highlighting the importance of human activities in causing fires, especially on peatlands.

The Oki District is one of the most fire prone areas in South Sumatra and the dynamics of forest and peatland fires make prevention and control of forest and peatland fires a top priority if these lands are to be managed sustainably, with reduced regional health impacts from haze and lower greenhouse gas emissions.

Acknowledgments: The authors are grateful to I Wayan Darmawan for his early review on the manuscript and Aswin Rahadian who help carried out this study. This research was supported by Institute of Research and community Empowerment (LPPM-IPB), fiscal year of 2021 (grant number 5503/IT3.L1/PT.01.03/ M/T/2021) and the International Tropical Timber Organization (ITTO). Cochrane's participation was funded through NASA grant 80NSSC20K0408.

Author Contributions: All authors contributed equally to this article

Conflict of Interest: The authors declare no conflict of interest

\section{References}

Andriesse, J. P. (1988). Nature and Management of Tropical Peat Soils. Soil Resources Management \& Conservation Service. FAO Land and Water Development Divisions.

[BAPPENAS] Badan Perencanaan Pembangunan Nasional. (1999). Final Report Annex l: Causes, Extent, Impact and Costs of 1997/98 Fires and Drought. Asian Development Bank Technical Assistance Grant TA 2999-INO, Planning for Fire Prevention and Drought Management Project. [Unpublished].

[BBSDLP] Balai Besar Sumberdaya Lahan Pertanian. (2011). Peta lahan gambut indonesia skala 1:250.000.

[BMKG] Badan Meteorologi, Klimatologi dan Geofisika (2019). Prakiraan Musim Kemarau 2019 di Indonesia. Retrivied from: https://www.bmkg.go.id/iklim/prakiraan- 
musim.bmkg?p=prakiraan-musim-kemarau-tahun-2019-di-indonesia\&tag=prakiraan

[BPS] Badan Pusat Statistik Ogan Komering Ilir.(2018). Kabupaten Ogan Komering Ilir Dalam Angka. Badan Pusat Statistik Kabupaten Ogan Komering Ilir, Sumatera Selatan. Retrieved from https://okikab.bps.go.id/publication/2018/08/16/e92c73890db87748e2affc74/kabupatenogan

[BPS] Badan Pusat Statistik Provinsi Sumatera Selatan. (2019). Provinsi Sumatera Selatan dalam Angka. Badan Pusat Statistik Kabupaten Ogan Komering Ilir, Sumatera Selatan. Retrieved from:https://sumsel.bps.go.id/publication/2019/08/16/2538e50f10441c67e0860a73/provin si-sumatera-selatan-dalam-angka-2019.html

Cattau, M. E., Harrison, M. E., Shinyo, I., Tungau, S., Uriarte, M., \& Defries, R. (2016). Sources of anthropogenic fire ignitions on the peat-swamp landscape in Kalimantan, Indonesia. Global Environmental Change, 39, 205-219. https://doi.org/10.1016/j.gloenvcha.2016.05.005.

Chandler, C., Cheney, P., Trabaud, L., \& Williams, D. (1983). Fire in Forestry: Forest Fire Management and Organization. John Wiley \& Sons, Inc.

Conrad E. (2009). Sistem Peringatan Dini untuk Manajemen Kebakaran di Kalimantan Tengah : Draf Panduan. International Research Institute for Climate and Society, Earth Institute, Columbia University, \& The Center for Climate Risk and Opportunity Management in Southeast Asia and the Pacific, IPB.

Endrawati. (2016). Analisis Data Titik Panas (Hotspot) dan Areal Kebakaran Hutan dan Lahan Tahun 2016. KLHK.

García, M. L., \& Caselles, V. (1991). Mapping burns and natural reforestation using Thematic Mapper data. Geocarto International, 6(1), 31-37. https://doi.org/10.1080/10106049109354290

Hooijer, A., Silvius, M., Wösten, H., Page, S., Hooijer, A., Silvius, M., Wösten, H., \& Page, S. (2006). PEAT-CO2, Assessment of $\mathrm{CO} 2$ emissions from drained peatlands in SE Asia. Delft Hydraulics Report Q3943.

Joosten, H. (2009). The Global Peatland CO2 Picture Peatland status and emissions in all countries of the world. Wetlands International.

[MoEF] Ministry of Environment and Forestry Republic of Indonesia. (2015). The 2105 Land and Forest Fire in Indonesia: Impacts, Efforts and Expectations. [Unpublished]

[MoEF] Ministry of Environment and Forestry Republic of Indonesia. (2016). The 2016 Forest and Land Fires in Indonesia. [Unpublished].

[MoEF] Ministry of Environment and Forestry Republic of Indonesia (2017). Keberhasilan dan Tantangan Pengendalian Kebakaran Hutan dan Lahan di Indonesia Tahun 2017. [Unpublished].

[MoEF] Ministry of Environment and Forestry Republic of Indonesia (2018). In Peraturan Menteri Lingkungan Hidup dan Kehutanan Republik Indonesia Nomor P.8/MENLHK/SETJEN/KUM.1/3/2018 Tentang prosedur Tetap Pengecekan Lapangan Informasi Titik Panas Dan/Atau Informasi Kebakaran Hutan Dan Lahan. Retrieved from http://jdih.menlhk.co.id/uploads/files/Untitled.pdf

[MoEF] Ministry of Environment and Forestry Republic of Indonesia (2020). Rekapitulasi Luas Kebakaran Hutan dan Lahan (ha) per Provinsi di Indonesia Tahun 2014-2019. Retrivied from: http://sipongi.menlhk.go.id/pdf/ luas_kebakaran.

Larastiti, C. (2018). Sonor dan Bias "Cetak Sawah" di Lahan Gambut. BHUMI: Jurnal Agraria dan Pertanahan, 4(1), 67-87. https://doi.org/10.31292/jb.v4i1.216

Maltby, E., \& Immirzi, P. (1993). Carbon dynamics in peatlands and other wetland soils regional and global perspectives. Chemosphere, 27(6), 999-1023. https://doi.org/10.1016/00456535(93)90065-D

Masganti, Wahyunto, Dariah A, Nurhayati, Yusuf R. (2014). Karakteristik dan potensi pemanfaatan lahan gambut terdegradasi di Provinsi Riau. Jurnal Sumberdaya Lahan, 8, 47-54.

Nurhayati, A. D., Hero Saharjo, B., Sundawati, L., Syartinillia, \& Vetrita, Y. (2020). Perilaku dan persepsi masyarakat terhadap terjadinya kebakaran gambut di Ogan Komeriling Ilir Provinsi Sumatera Selatan. Jurnal Pengelolaan Sumberdaya Alam dan Lingkungan (Journal of Natural Resources and Environmental Management), 10(4), 568-583. 
https://doi.org/10.29244/jpsl.10.4.568-583

Page, S. E., \& Hooijer, A. (2016). In the line of fire: the peatlands of Southeast Asia. Philosophical Transactions of the Royal Society B: Biological Sciences, 371(1696), 1-9. http://dx.doi.org/10.1098/rstb.2015.0176

Peraturan Pemerintah Republik Indonesia Nomor 57 Tahun 2016 Tentang Perubahan Atas Peraturan Pemerintah Nomor 71 Tahun 2014 Tentang Perlindungan Dan Pengelolaan Ekosistem Gambut. Retrivied from https://sipuu.setkab.go.id/PUUdoc/175063/PP\%20No\%2057\%20Tahun\%202016.pdf

Putra, E. I., Cochrane, M. A., Vetrita, Y., Graham, L., \& Saharjo, B. H. (2018). Determining critical groundwater level to prevent degraded peatland from severe peat fire. IOP Conference Series: Earth and Environmental Science, 149(1). https://doi.org/10.1088/1755-1315/149/1/012027

Ratmini, N., \& Yohanes, Y. (2014). Kajian Tanam Sistem Sonor terhadap Varietas Unggul Padi di Lahan Pasang Surut Sumatera Selatan (Studi Kasus di Daerah Pasang Surut Telang). Jurnal Lahan Suboptimal, 2(1), 75-80. https://doi.org/10.33230/JLSO.2.1.2013.38.

Saharjo, B. H. (2006). Pengendalian Kebakaran secara tradisional. Buletin Hot Spot. South Sumatra Forest Fire Management Project.

Saharjo, B. H., Syaufina L., Nurhayati A. D., Putra E. I., Wardana. (2017). Pemanfaatan lahan gambut dan emisi gas rumah kaca. IPB Press.

Solichin. (2004). Kecenderungan Kebakaran Hutan di Sumatera Selatan: Analisis Data Historis Hotspot NOAA dan MODIS. South Sumatera Forest Fire Management Project.

Stockwell, C. E., Jayarathne, T., Cochrane, M. A., Ryan, K. C., Putra, E. I., Saharjo, B. H., ... \& Yokelson, R. J. (2016). Field measurements of trace gases and aerosols emitted by peat fires in Central Kalimantan, Indonesia, during the 2015 El Niño. Atmospheric Chemistry and Physics, 16(18), 11711-11732. https://doi.org/10.5194/acp-16-11711-2016

Syaufina, L. (2008). Kebakaran hutan dan lahan di Indonesia: perilaku api, penyebab, dan dampak kebakaran. Bayumedia.

Syaufina L., Siwi R., Nurhayati AD. (2014). Ratio of Hotspot Source as an Indicator of Forest and Peat Fire and Its Correlation with Rainfall in Sepahat Village, Bengkalis District, Riau. Jurnal Silvikultur Tropika, 5(2), 113-118. https://doi.org/10.29244/j-siltrop.5.2.\%25p

Tacconi L. (2003). Kebakaran Hutan Di Indonesia: Penyebab, Biaya dan Implikasi Kebijakan. CIFOR Occasional Paper No. 38(i). CIFOR.

Tarigan, M. L., Nugroho, D., Firman, B., \& Kunarso, A. (2015). Laporan dan Modul Teknis Pemutakhiran Peta Rawan Kebakaran Hutan dan Lahan di Provinsi Sumatera Selatan. Palembang. Retrieved from: http://forclime.org > bioclime.org > publications.

Taufik, M., Setiawan, B. I., \& van Lanen, H. A. J. (2015). Modification of a fire drought index for tropical wetland ecosystems by including water table depth. Agricultural and Forest Meteorology, 203, 1-10. https://doi.org/10.1016/j.agrformet.2014.12.006

Trinimalingrum, Dalidjo, N., Widyanto, F. R. S. U., Achsan, I. A., Primandari, T., \& Wardana, K. W. (2015). Di Balik Tragedi Asap : Catatan Kebakaran Hutan dan Lahan 2015. SETAPAK.

Turetsky, M. R., Benscoter, B., Page, S., Rein, G., van der Werf, G. R., \& Watts, A. (2015). Global vulnerability of peatlands to fire and carbon loss. Nature Geoscience, 8(1), 11-14. https://doi.org/10.1038/ngeo2325

Wahyunto \& Heryanto, B. (2005). Sebaran Gambut dan Status Terkini di Sumatera. Wetlands International-Indonesia Programme.

Wahyunto, Ritung, S., Suparto, \& Subagjo. (2005). Sebaran Gambut dan Kandungan Karbon Pulau Sumatera dan Kalimantan. Wetlands International-Indonesia Programme.

Wahyunto, Ritung S, Nugroho K, Sulaiman Y, Hikmarullah, Tafakresnanto C, Suparto dan Sukarman. (2013). Peta Arahan lahan Gambut Terdegradasi di Pulau Sumatera Skala 1:250.000. Badan Penelitian dan Pengembangan Pertanian. Kementerian Pertanian.

Widyati E. (2011). Kajian Optimasi Pengelolaan Lahan Gambut dan Isu Perubahan Iklim. Jurnal Tekno Hutan Tanaman, 4(2), 57-68.

World Bank Group. (2016). Kerugian dari Kebakaran Hutan: Analisa Dampak Ekonomi dari Krisis Kebakaran Hutan Tahun 2015. World Bank. 
Yananto A dan Dewi S. (2016). Analisis Kejadian El Nino Tahun 2015 dan Pengaruhnya Terhadap Peningkatan Titik Api di Wilayah Sumatera dan Kalimantan. Jurnal Sains \& Teknologi Modifikasi Cuaca, 17(1), 11-19. https://doi.org/10.29122/jstmc.v17i1.544 